NOMOI

LAW REVIEW $\begin{aligned} & \text { E-ISSN: 2722-3663 } \\ & \text { Volume 1, Issue 1, May 2020 }\end{aligned}$

\title{
INSTITUTIONAL FUNCTION REGIONAL FINANCES IN MANAGING REGIONAL ASSETS IN INDONESIA
}

\author{
Nurmalawaty \\ Faculty of Law, University of North Sumatera \\ nurmalawaty@ rocketmail.com
}

\begin{abstract}
Regional autonomy as the beginning of decentralization has the urgency to be implemented for the progress of the State. Regional financial institutions often occur collusion triangles with regional heads so that they do not guarantee the implementation of good regional government because of the management of suboptimal regional assets. The need for maximizing the functions of regional institutions so that regional assets can be managed for regional progress evenly. The absence of special regulations regarding the management of regional finance is a problem because it still uses state financial laws so that the recommendations that the authors recommend in the form of optimizing regional financial institutions in managing regional assets and the existence of special regulations that regulate in detail the management of regional assets. The method used in this study is a normative juridical legal research method.
\end{abstract}

\section{Keywords: Institutional Function, Regional Finances, Regional Assets}

\section{INTRODUCTION}

Decentralization is a tool to achieve one of the objectives of the state and is also influenced by the optimal functioning of institutions in the regions in managing regional assets including regional income and expenditure budgets as a form of regional financial management. In general, financial management reforms are motivated by several preconditions that lead to increase central financial management positions in local governments. This precondition, for example, is increasing in the need to renew regulations, monitor financial management, and limited funding sources. In terms of regulation, the need to replace financial legislation that still refers to the legacy of the colonial government is increasingly urgent.

Regional Finance must be managed in an orderly manner, obeying the laws and regulations, being efficient, economical, effective, transparent and responsible with due regard to justice, propriety and benefits to the community. On the other hand, the demands of transparency, and accountability in the government system are increasing in the current reform era, including transparency in the financial management of the Regional Government.

Regional financial management, which is the management of the Regional Budget (RB), is very crucial and becomes an important element in assessing the success of 
regional governments in managing the $\mathrm{RB}$. Legislative $^{1}$ and Executives in Regional Governments(LGs) in this case the Regional People's Representatives Council (RPRC) and Regional Heads consisting of Governors, Regents, Mayors and all Regional Work Units (MRWU) strongly associated with regional financial assistance can run well or not.

Article 311 paragraph (1) Minister of Home Affairs Regulation Number 21 of 2011 concerning Guidelines for Regional Financial Management The lack of supervision from the RPRC has been approved in the face of the chaotic management of regional finances in Indonesia as evidenced by the sum insured carried out by the collusion triangle, namely by the Regional Head, RPRC and MRWU.

The Corruption Eradication Commission (CEC) helped resolve corruption cases committed by the Regional Government, with an inkracht ruling in 2015 of 38 cases, in 2016 as many as 71 cases and 2017 as many as 84 cases. ${ }^{2}$ The Representative and RPRC rank 3 as contributors to the number of corruptors in the CEC, which are 144 cases. ${ }^{3}$ Meanwhile, MRWU that committed

${ }^{1}$ The legislature is a branch of power which first reflects the sovereignty of the people. State activities, first of all, are to regulate life together. Jimly Asshiddiqie, Pengantar Ilmu Hukum Tata Negara, (Jakarta: PT RajaGrafindo Persada, 2016), p. 298.

${ }^{2}$ Statistik Anti Coruption Clearing House, "Angka Korupsi dari tahun ketahun", melalui www.acch.CEC.go.id, accessed on Monday, 23 April 2018.

${ }^{3}$ Kumparan NEWS, "Jumlah Anggota RPRC Korupsi Tahun 2017”, melalui
25 corruption cases. $^{4}$ The data, only limited to prosecution by the CEC and outside the corruption cases handled by the prosecutor's office and the police.

The rise of corruption cases towards the management of the Regional Budget as proof that the supervision of the parties who are obliged to carry out it does not carry out their duties optimally so that solutions are needed to organize regional financial management. The oversight function of the RPRC in managing the RB is not empowered so that it experiences cheating on RB burglary carried out by regional heads and MRWU. RPRCs that are supposed to strictly supervise participate in corruption.

The basic principles in the preparation of RB must be carried out with public participation, transparency, and accountability of budgets, budgetary discipline, the fairness of budget, efficiency and effectiveness of budgets and compliance with the principle of not contradicting laws and regulations that are of higher public interest and other regional regulations. $^{5}$

It seems that the basic principles have been ignored so that the management of the Regional Budget that ticks swimmers has not been able to efficiently and effectively accommodate public interests. If the optimization of the RPRC's function in managing the $R B$ is

www.kumparan.com, accessed on Monday, 23 April 2018.

${ }^{4} \mathrm{CEC}$ (Antara), "StatistikCEC, JumlahMRWU yang korupsi",melalui www.okezone.com, accessed on Monday, 23 April 2018.

${ }^{5}$ Pramono Hariadi, dkk. Pengelolaan Keuangan Daerah (Jakarta: Penerbit Salemba Empat, 2010), p. 11-12. 
maximized, the results of the management of the Regional Budget have the potential to make the prosperous society evenly if managed optimally and optimally.

Influence is not optimal management of regional benefits because LGs that prioritize personal interests compared to the interests of the wider community certainly have an impact on the people who should get their rights to the RB allocation.

The chaos, corruption in the management of the RB is also carried out by the parties who manage it. The existence of a collusion triangle resulted in the people being destitute because the allocation of funds that should have been for the public interest was deviated from personal pockets.

The need for a strategy to empower the oversight function of the RPRC in managing the $\mathrm{RB}$ with a preventive step in the form of misappropriation of the Regional Budget with provisions that are can ensnare and bind the Regional Budget supervisors to carry out their functions by the legal corridor.

In connection with these facts, the author is interested in raising and reviewing the title of the research on the "Institutional Function Regional Finances In Managing Regional Assets In Indonesia".

\section{METHOD}

The nature of research in completing this thesis is analytical descriptive writing that leads to normative juridical, namely finding the truth of coherence. ${ }^{6} \mathrm{~A}$

6 Peter Mahmud Marzuki, Penelitian Hukum (Jakarta: Prenada Media Group, 2011), p. 47. normative study must use a statute approach, this is because various legal rules are the examined subject. ${ }^{7}$ This kind of research is also called doctrinal research $^{8}$ in Dworkin's term, ie research that analyzes the law, both written in the book (law as it is written in the book). In this study, library materials and document studies are used as the main material while the field data obtained through interviews will be used as supporting data or complementary in terms of clarification of the data.

\section{DISCUSSION}

The need for a strategy to empower the oversight function of the RPRC in managing the $\mathrm{RB}$ with a preventive step in the form of misappropriation of the Regional Budget with provisions that are able to ensnare and bind the Regional Budget supervisors to carry out their functions in accordance with the legal corridor. Some subjects are authorized to manage the Regional Budget in an area, namely:

1. Regional Financial Management Work Unit hereinafter abbreviated as SCECD is a regional apparatus in the regional government as a budget user/user of goods, which also implements regional financial management. (Article 1 number 11 Minister of Home Affairs Regulation (MHAR) Number 21 of 2011

${ }^{7}$ Researchers must see the law as a closed system, with the following characteristics.

8 Hendra Karianga, Carut Marut Pengelolaan Keuangan Daerah di Era Otonomi Daerah Perspektif Hukum dan Politik (Depok: Kencana, 2017), hlm. 105 


\section{LAW REVIEW E-ISSN:2722-3663

concerning Guidelines for Regional Financial Management (RFM), hereinafter abbreviated as MHAR No. 21 of 2011 concerning RFM).

2. Organizations are elements of the regional government consisting of RPRC, regional heads/deputy regional heads and regional apparatus working units (Article 1 number 12 MHAR No. 21 of 2011 concerning RFM).

3. The Regional Head is the governor for the province or regent for the regency or mayor for the city area (Article 1 number 13 MHAR No. 21 of 2011 concerning RFM).

4. Holder of Regional Financial Management Power is a regional head who, because of his position, has the authority to organize overall regional financial management (Article 1 number 14 MHAR No. 21 of 2011 concerning RFM).

5. Regional Financial Management Officer, hereinafter abbreviated as RFM, is the head of the regional financial management work unit hereinafter referred to as the SCECD head who has the task of managing the $\mathrm{RB}$ and acting as the regional general treasurer (Article 1 number 15 MHAR No. 21 of 2011 concerning RFM).

6. Regional General Treasurer, hereinafter abbreviated as BUD, is RFM acting in the capacity as regional general treasurer (Article 1 number 16 MHAR No. 21 Year 2011 concerning RFM).

7. Budget Users are officials who hold the authority to use the budget to carry out the main tasks and functions of the MRWU they lead (Article 1 number 17 MHAR No. 21 of 2011 concerning RFM).
8. MRWU Financial Administration Officer, hereinafter abbreviated as PKK-MRWU, is an official who implements financial administration functions at MRWU (Article 1 point 21 MHAR No. 21 of 2011 concerning RFM).

9. Activity Technical Executing Officer, hereinafter abbreviated as ATIO, is an official in the MRWU work unit who carries out one or several activities from a program according to their field of work (Article 1 number 22 MHAR No. 21 of 2011 concerning RFM).

10. Receiving Treasurer is a functional official appointed to receive, store, deposit, administer and account for regional income money in the context of implementing the RB on MRWU (Article 1 point 23 MHAR No. 21 of 2011 concerning RFM).

11. Expenditure Treasurer is a functional official appointed to receive, save, pay for, administer and account for the money for regional expenditure in the context of implementing the $\mathrm{RB}$ on MRWU (Article 1 point 24 MHAR No. 21 of 2011 concerning RFM).

The principle of implementing goods and services procurement is a norm that must be adhered to by state / regional financial management officials. The PBJ principle must also be internalized in every stage of PBJ planning and implementation. Denial of PBJ principles will fail to achieve PBJ objectives. ${ }^{9}$

${ }^{9}$ Hendra Karianga, Disorganized Regional Financial Management in the Era of Regional Autonomy Legal and Political Perspectives (Depok: Kencana, 2017), p. 105. 


\section{LAW REVIEW $\begin{aligned} & \text { E-ISSN:2722.3663 } \\ & \text { Volume }, \text { Issue } 1 \text {, May } 2020\end{aligned}$}

The Multiyear Budgeting System (MYBS) is part of local government policies to overcome funding constraints in the context of accelerating development that develops rapidly as part of sustainable development efforts to meet the basic needs of the people and accelerate the achievement of people's welfare in the era of regional autonomy. state finance law as a legal umbrella (Law No. 17 of 2003, Law No.1 of 2004, Law No. 15 of 2004). ${ }^{10}$

The provisions of MHAR Number 21 Year 2011 clarify and reinforce the legal framework for implementing the multiyear budgeting system (MYBS) in the context of budget order and ensuring accountability of budgeting by regional governments while realizing good financial governance (GFG). ${ }^{11}$

Business plans and budgets also contain forward estimates following applicable laws and regulations. The business plan and budget are compiled by adhering to a flexible budget pattern (flexible budget) with a certain percentage threshold. ${ }^{12}$ The importance of ensuring all the terms of the work contract (contract of work) can be implemented both the time of implementation, the type of activity, and the availability of funds. If not, it will create legal and political implications that can be detrimental to many parties (community, government, and contractors). ${ }^{13}$

Another problem that needs to be observed is the issue of tender conspiracy.

\footnotetext{
${ }^{10} I b i d .$, p. 107.

${ }^{11}$ Ibid., p. 109.

12 Muhammad Djafar Saidi, Hukum
} Keuangan Negara, (Jakarta: PT RajaGrafindo Persada, 2011), p. 166.

${ }^{13}$ Loc. Cit.,
Tender conspiracy is a type of action prohibited by law, both Law Number 5 Year 1999 concerning Prohibition of Monopolistic Practices and Presidential Decree 80 of 2003 concerning Procurement of Goods and Services. The practice of tender conspiracy usually starts at the time of program planning, announcements, and implementation by the government. There were various agreements regarding the volume of work, fees that must be received. ${ }^{14}$

In the organizers of the state, corruption is usually done by means: ${ }^{15}$

1. Mark up unit prices for goods and services.

2. Tender manipulation by arranging winners.

3. Slow down the Election schedule in various ways and reasons.

Voting is channeled through the envoys they sit in the representative forum $($ demos + cratein $=$ people + rule $)$. Generally, the people's representative council (parliament) has 2 (two) types of main tasks, namely (a) legislative tasks (wetgeving; law making) and (b) supervisory duties (control of the executive). ${ }^{16}$

Bernard Rosen explicitly stated, "By making laws that establish what the administrative bodies are and the right to hold the administrators accountable." So, those responsible are not only the executive and the bureaucracy., but also the legislative body, the judicial body, political parties, and the entire community by asserting that the legislature also has

\footnotetext{
${ }^{14}$ Hendra Karianga, Op. Cit., p.111.

${ }^{15}$ Ibid., p. 130.

${ }^{16}$ M. Solly Lubis, Hukum Tata Negara
} (Bandung: Mandar Maju, 2008), p. 62-63. 


\section{LAW REVIEW $\begin{aligned} & \text { E-ISSN: 2722-3663 } \\ & \text { Volume } 1, \text { Issue 2, May 2020 }\end{aligned}$}

the authority and power to make a government accountable. Thus, all institutions that hold the power of the state and their communities must be responsible, both to themselves, the mandate, and the natural environment. ${ }^{17}$

\section{Institutional Function of Regional Finance in Managing Regional Assets}

According to the construction of the interpretation of the provisions of Article 23 of the 1945 Constitution stated by A. Hamid S. Attamimi, the financial meaning of the State is not only limited to the State Expenditure Budget (SEB), but also the Regional Expenditure Budget (RB), and State-Owned Corporate Finance. Regarding the provisions of Article 23 of the 1945 Constitution, Arifin P. SoeriaAtmadja also provides an interpretation of the definition of State finance. ${ }^{18}$

Article 23 of the third (third) preamendment to the 1945 Constitution as expressed by Arifin, is also confirmed by JumlyAsshiddiqie's opinion which states: The definition of the income and expenditure budget referred to in the 1945 Constitution is only the State Revenue and Expenditure Budget (SEB), so not covered by the Regional Revenue and Expenditure Budget (RB) which is not at all related to the duties and authorities of the Supreme Audit Agency.

Main tasks and functions as well as authorities in structural positions and determination of functional positions in the Regional General Treasurer, Regional

${ }^{17}$ Hendra Karianga, Op. Cit., p. 155.

${ }^{18}$ Arifin P. Soeria Atmadja, Keuangan Publik dalam Perspektif Hukum Praktik dan Kritik (Jakarta: Badan Penerbit Fakultas Hukum Universitas Indonesia, 2005), hlm. 15.
General Treasurer Authority, MRWU Regional Finance Administration Officer (RFAO) and Activity Technical Implementation Officer (ATIO); there are often conditions in the field that are difficult to avoid that functional positions are still concurrent with structural positions, therefore the following is conveyed a matrix of inter-institutional connectivity to avoid these conditions.

Administration of regional financial management mandated in Decree of the Minister of Home Affairs (DMHA) No $29 / 2002$ is also almost the same as the Regional Financial Administration Manual even though the budget system adopted is different. RB began to be implemented since the Work Unit Budget Document (WUBD) was approved by the regional head as a document for implementing the Regional Budget. The WUBD is then processed with an Authorization Decree (AD), Payment Request, Money Paying Order, and Accountability.

All of these processes are carried out by executors of activities in work units by centralizing financial management in the financial section of the Regency/City Government and financial bureaus in the Provincial government. Furthermore, fundamental changes have only occurred since the enactment of Law No. 1 of 2004 concerning Treasury and MHAR No. 13 of 2003, where the drafting of documents on the implementation of the budget is decentralized in the work unit. The RB implementation begins with the preparation of the Regional Work Unit Budget Implementation Documents. Based on the DPA-MRWU, then the Regional Financial Management Officer issues a Letter of Request for Funds (RF). Based on the RF, the treasurer at the MRWU 
prepares a Request for Assistance for various MRWU expenditure expenses. Furthermore, the Head of MRWU as the budget user issues a Payment Order under the verified SPP. The issued SPM is then submitted to the BUD's power of attorney for the issuance of a Fund Disbursement Order (IFDO). Furthermore, IFDO is used as the basis for disbursing funds in the Regional Treasury.

Examination and Supervision of State Finance as stipulated in Law Number 17 of 2003 concerning State Finance, that State power, that the power of state financial management is held by the President as head of Government, and authorized by the Minister of Finance and Minister/head of institutions as Budget Users / Goods User of the state ministry/institution he leads.

The holders of government financial management authority have an institution/agency/unit supervisory apparatus within the government that has the duty and function of conducting supervision, namely the Government Internal Supervisory Apparatus (GISA), which consists of: (1) Financial and Development Supervisory Agency (DSA) ), (2) Inspectorate General. Furthermore, regarding the examination of state finances, the 1945 Constitution regulates in the provisions of Article $23 \mathrm{E}$ which says:To examine the management and responsibilities of state finances, a free and independent Supreme Audit Agency (SAA) is held.The provisions of Article 9 paragraph (1) of the Law of the Supreme Audit Agency are said "In carrying out its duties, the SAA is authorized:

a. Determine the object of inspection, plan, and carry out the examination, determine the time and method of examination and compile and present the inspection report;

b. Request information and/or documents that must be provided by each person, central government organizational unit, regional government, other state institutions, Bank Indonesia, StateOwned Enterprises, Public Service Bodies, State-Owned Enterprises, and other institutions or entities that manage finances country;

c. Conduct inspection at the depository of money and goods belonging to the state, at the place of the activities, bookkeeping, and administration of state finance, as well as inspection of calculations, letters, evidence, checking accounts, liability, and other lists relating to financial management country;

d. Determine the types of documents, data, and information regarding the management and responsibility of state finances that must be submitted to the SAA;

e. Set standards for examining state finances after consultation with the central/regional government that must be used in the examination of management and responsibility of state finances;

f. Establish a code of ethics to examine the management and responsibility of state finances;

g. Use experts and / or examiners outside the SAA who work for and on behalf of the SAA;

h. Fostering the functional position of the Examiner;

i. Consider to Government Accounting Standards;

j. Consider to the design of the internal control system of the central / regional 


\section{LAW REVIEW $\begin{aligned} & \text { E-ISSN:2722-3663 } \\ & \text { Volume } 1 \text {, Issue 1, May 2020 }\end{aligned}$}

government before being determined by the central / regional government".

Monitoring activities and the results of the SAA examination, according to Article 10 paragraph (4), must be notified in writing to the DPR, DPD and RPRC in by with their authority. The position of the Financial and Development Supervisory Agency of the Financial and Development Supervisory Agency (FDSA) is a nondepartmental government agency that is under and directly responsible for carrying out the main tasks referred to above.

The FDSA has functioned as contained in the provisions of Article 3 of Presidential Decree No. 31 of 1983, namely:

a. Formulate planning and supervision implementation programs for the FDSA and prepare planning formulations and supervision implementation programs for all apparatus of supervision of the Central Government and Regional Government;

b. Providing guidance and guidance in the field of supervision;

c. Monitor the implementation of the supervision plan and analyze of the results of supervision of the Central Government and Regional Government;

d. Preparing inspection guidelines for all Central Government and Regional Government supervision officers;

e. Coordinating technically regarding the implementation of supervision carried out by supervisory authorities in the Departments and other Government Agencies both at the Center and in the Regions;

f. Improve the technical skills of all supervisory officers of the Central Government and Regional Government; g. Technical skills of all supervisory officers of the Central Government and Regional Government, including supervision of the implementation of the tax, customs, and excise facilities;

h. Supervise all receipts of the Central Government and Regional Government;

i. Supervise the management of goods belonging to the Central Government and the Regional Government;

j. Supervise all State-Owned Enterprises, Regionally-Owned Enterprises and other business entities whose entire or part of their property is owned by the Central Government or Regional Government;

k. Supervise other bodies in which there are financial interests or other interests of the Central Government or Regional Government due to the granting of rights or Regional Government due to the granting of rights or authority of public law; President. One of the considerations for the establishment of the FDSA by Presidential Decree No.31 of 1983, is to increase supervision of existing state finances

1. Supervise the administrative system for the implementation of the Regional Revenue and Expenditure budget, StateOwned Enterprises, Regional-Owned Enterprises, including the accounting of Government accounts at the Bank;

$\mathrm{m}$. Evaluate the administrative work procedures that have been determined by each agency;

n. Conducting special checks on cases of ineffective implementation of development and cases that are thought to contain elements of irregularities that are detrimental to the Government, Regional Government, State-Owned 


\section{LAW REVIEW $\begin{aligned} & \text { E-ISSN: 2722-3663 } \\ & \text { Volume 1, Issue 1, May } 2020\end{aligned}$}

Enterprises and Regionally-Owned Enterprises;

o. Conduct audits of accountants to provide accountants' opinion statements to State-Owned Enterprises, Regionally-Owned Enterprises, and other Bodies deemed necessary;

Supervise public accounting offices. Regional financial institutions, where the holder of the Regional Financial Management Authority of the Governor as the representative of the Central Government coordinates the implementation of planning for deconcentration and co-administration tasks. The regional head organizes and is responsible for regional development planning in his area. In conducting regional development planning, the Regional Head is assisted by the Head of Bappeda. MRWU leadership organizes regional development planning in accordance with their duties and authorities. The Governor organizes coordination, integration, synchronization, and synergy of development planning between districts / cities.

MHAR No. 13 of 2006 which was later amended by Permedagri No.59 of 2007 concerning Amendments to the Minister of Home Affairs Regulation No. 13 of 2006 concerning Guidelines for Regional Financial Management also mentioned in Article 5 (1) that:

The Regional Head as Head of the Regional Government is the holder of the power of regional financial management and represents the regional government in the ownership of separated regional assets. The regional head as the holder of the power of regional financial management delegates part or all of his power to:
1. Regional Secretary as coordinator of regional financial management;

2. Head of the Regional Finance Management Work Unit (hereinafter referred to as SCECD) as Regional Finance Management Officer (hereinafter referred to as RFM); and

3. Head of MRWU as a budget user / item user official.

Delegation of this power is determined by the decision of the regional head based on the principle of separation of authority between those who order, test, and receive or issue money. In its implementation, the regional financial management coordinator is the regional secretary. This coordinator has coordination tasks in the fields:

1. Preparation and implementation of regional goods management policies;

2. Preparation of the draft RB and draft changes to the RB;

3. Preparation of the Regional Budget Draft, changes in RB, and implementation accountability RB;

4. In addition, coordination of regional financial management also has duties;

5. Lead the local government budget team;

6. Prepare guidelines for implementing the Regional Budget;

7. Prepare regional goods management guidelines;

8. To approve the approval of the DPA MRWU;

9. Carry out the tasks of coordinating other regional financial management.

10. These tasks are based on the power delegated by the regional head. Besides that, the regional financial coordinator is responsible for carrying out his duties to the Head Area. 
Regional Finance Management Officer in Article 7 MHAR No. 13 of 2006 which was later amended by Permedagri No. 59 of 2007 concerning Amendments to the Regulation of the Minister of Home Affairs Number 13 of 2006 concerning Guidelines for Regional Financial Management stated that the Head of the SCECD as RFM has the following:

1. Prepare the draft RB and draft changes to the RB;

2. Carry out regional revenue collection which has been determined by regional regulations;

3. Carry out the functions of the Regional General Treasurer (BUD);

4. Prepare regional financial reports in the framework of accountability for the implementation of the Regional Budget;

5. Carry out other duties based on power delegated by the regional head.

Acting Budget Users / Regional Property Users in Article 10 Government Regulation No. 58 of 2005 concerning Management of Regional Finance states that officials of regional budget / goods users have the following duties and authorities: Make a RKA MRWU,

1. Arranging the DPA MRWU,

2. Take action that results in expenses at the expense of the budget,

3. Carrying out the MRWU budget he leads,

4. Test the bills and order payments,

5. Carrying out non-tax revenue collection,

6. Hold a bond / cooperation agreement with another party within the set budget limit,

7. Managing debts and receivables which are the responsibility of the MRWU they lead,Managing the property of the area / wealth of the region which is the responsibility of the MRWU he leads, Arrange and submit MRWU

8. financial reports that they lead Oversee the implementation of the MRWU budget he leads, Carry out the tasks of budget users / other users of goods based on the power delegated by the head of the region, Responsible for carrying out his duties to the regional head through the regional secretary.

Technical Executing Officers of MRWU Activities Officials of budget users / goods users and power of budget users / power users of goods in carrying out programs and activities appoint officials to MRWU work units as Acting Technical Acting Officers (ATIO). The appointment is based on consideration of budget position competency activities, workload, location and / or range of control, and other objective considerations ATIO appointed to be responsible for carrying out their duties to budget users / users of goods. ATIO's duties include:Mengendalikanpelaksanaankegiata $\mathrm{n}$;

1. Report the progress of the implementation of activities;

2. Preparing documents;

3. Budget for expenses for carrying out activities;

4. The budget document includes administrative documents of activities as well as administrative documents related to payment terms stipulated in accordance with statutory provisions.

Position of RPRC in Managing Regional Finance In the era of regional autonomy, the role of RPRC has become increasingly important in addition to the extent of regional executive authority. In 
regional financial matters, the RPRC is involved in:

1. Determination (joint agreement) of the Draft Regional Regulation into Regional Regulations concerning the Regional Budget.

2. Supervision of regional government, including the implementation of regional financial management, also includes the implementation of the Regional Budget.

This situation can be anticipated by cooperating with existing state financial management oversight institutions, both internal institutions, such as the Financial and Development Supervisory Agency (hereinafter referred to as the FDSA) and the Regional Supervisory Agency

(hereinafter referred to as regional controller) and the government esk PBK. The Supreme Audit Agency (SAA) is the only state financial management audit agency. ${ }^{19}$

Development is a planned improvement effort towards a better life. Goulet in Syaukani ${ }^{20}$ provide development concepts related to human needs to three main components; survival (life sustenance), self respect (self esteem), and freedom (freedom). This is what a country wants to achieve in carrying out, not only survival, but also able to display selfrespect and freedom by promoting authenticity, self-identity, glory, and recognition.

${ }^{19}$ Mulia P. Nasution, Government Financial Management Reform, Journal of the Innovation Forum December-February (2003).

${ }^{20}$ Syaukani, HR, Otonomi Daerah demi Kesejahteraan Rakyat (Jakarta: Nuansa Madani, 2004), p. 2.
Strategy for Managing Regional Assets by Empowering Regional Financial Institutional Functions

In principle, the main framework of political strategy regarding the development / development of national law for three decades has the same basic concept, namely the 1945 Constitution. The ideal foundation is the same, namely Pancasila, the operational political foundation is the same, namely the national goals stated in the Preamble, and The structural basis of government institutions that will support the development burden is the same, namely the presidential government system. ${ }^{21}$

Reviewing the formation and renewal of law will not be separated from the operation of the three components of

the legal system proposed by Friedmann, namely substance, legal structure, and legal culture. Legal development and renewal in the view of SatjiptoRahardjo is based on the nature of the law itself as a regulation whose enactment must meet philosophical, political, juridical and sociological requirements. ${ }^{22}$

The history of the formation of the law on state financial management and regional finance cannot be separated from the paradigm of the country as a unitary state that focuses on decentralization and regional autonomy which aims to develop regional capacity, empowerment and capability to accelerate the realization of community welfare. state finance and regional financial law directed at the welfare of the community as the

\footnotetext{
${ }^{21}$ HendraKarianga, Op. Cit., p. 27.

${ }^{22}$ Ibid., p. 28.
} 
embodiment of the state goals set out in the opening of the 1945 Constitution of the Republic of Indonesia. ${ }^{23}$

The management of state finances, especially regional finance, is in the dimension of appreciation and protection of people's human rights in the economic, social and cultural aspects. This has consequential implications for the management of state / regional finances, which are placed not only as legal rights but more than that state / regional financial management is constitutional right (constitutional rights). ${ }^{24}$ Indicators to be able to know the degree of constitutionalism in the management of state and regional finances in, particular, this can be seen to what extent local governments have commitment and integrity in protecting and realizing guarantees for the basic rights of their communities. ${ }^{25}$

The ideal direction of legal politics in regional financial management is regional financial management in a constitutional dimension, namely in the framework of the realization of a state of law and welfare state. This is done, among others, by the progress of budget policies in managing regional finance to prioritize community needs and avoid disorientation of budget policies that lead to inefficient use of the budget. ${ }^{26}$

The direction of the development of regional financial management law based on the protection and fulfillment of human rights in the economic, social, and cultural fields requires a law formation which is

\footnotetext{
${ }^{23}$ Ibid., p. 31.

${ }^{24}$ Ibid., p. 32.

${ }^{25}$ Ibid.

${ }^{26}$ Ibid.
}

carried out with a balance between procedural orientation and substantive orientation. Procedural orientation through community involvement in regional financial management and substantive orientation with budget allocations in regional financial management for the benefit of the people as sovereignty owners. $^{27}$

Bureaucracy must be built based on certain ideal characteristics, namely first the existence of specialization or division of labor. In the bureaucracy there must be a clear division of labor. Bureaucracy needs to be divided into parts, each of which has a distinctive function. Each of these parts is carried out by employees who have expertise that is in accordance with their respective fields of duty and must be given clear and explicit responsibilities. Equally important is the existence of an authoritarian hierarchy. In the bureaucracy body, there must be a hierarchy with pyramid-level authority, namely the higher the level in the organizational structure, the fewer people, but the greater the authority. The existence of this hierarchy gives firm authority between superiors and subordinates, between those who govern and those governed, and between those who supervise and those supervised.

Second, regulating the behavior of bureaucratic answer holders. The rules of the game formulate the scope of responsibilities of officeholders in various positions and ensure the coordination of various tasks carried out from various activities. Third, the existence of impersonal group relations. The mechanism of work of the bureaucracy

${ }^{27}$ Ibid. 
must also be neutral and impersonal. In carrying out public policies stipulated by politicians and in providing services to the bureaucratic community, they do not look at their perceptions, do not view the personal connection between bureaucrats and individuals served.

Fourth, there are technical capabilities. Each part of the bureaucracy is run by employees who have expertise in by with their respective fields of work which are usually based on the results of tests and certificates. Therefore the process of recruiting bureaucrats is central in building the ideal bureaucratic figure.

Finally, there is a career system. To build individual bureaucrats who will work fully for the benefit of the organization, Weber suggested implementing a career system. In this career system promotion is carried out on the basis of seniority and / or achievement. This is in line with the principle of a strict pyramid-shaped hierarchy of authority.

With the reform or renewal in the regional financial accountability system, the old system that has been used by the Regional Government both provincial and district / city governments is the Regional Financial Administration Manual which has been implemented since 1981. The old system with features, including single entry ( single bookkeeping), incremental budgeting (traditional budgeting routine and development) and a dynamic balanced budget approach are no longer able to meet regional needs, for several reasons, including the Budget Implementation Responsibility Stages which include:

1. Not able to provide information about wealth owned by the region, or in other words unable to provide a balance sheet;
2. Not able to provide information about cash flow reports so that management or the public cannot know what factors

3 . cause an increase or decrease in regional cash; and

4. Not able to provide information about regional wealth.

Where we believe that some of the reasons above are the initial steps for reforming the Human Resources in Finance. In carrying out regional financial management activities, local financial managers need to organize well. In MHAR 21/2011, MHAR 59/2007 and MHAR 13/2006 concerning Regional Financial Management Guidelines can be classified into 4 main activity rules, namely: 1) budget planning which includes budget formulation and stipulation, 2) budget implementation, 3) budget changes , 4) accountability for budget execution. The four main activities are also regulated in terms of cash management, administration and accounting and regional financial reporting. Whereas the supervision of the implementation of the budget is regulated by separate provisions and carried out by the Regional Supervisory Unit. Treasurer, civil servant, not treasurer, or another official who, because of his or her actions violating the law or neglecting the obligations imposed on him directly to the detriment of the state, must replace the said loss.

1. Each leader of the state ministry / institution / head of the Regional Work Unit (MRWU) can immediately make compensation claims after knowing that in the relevant state / institution / MRWU ministry there is a loss due to the actions of any party.

2. Every regional loss must be reported by the direct supervisor or the head of the 


\section{LAW REVIEW E-ISSN:2722-3663

MRWU to the governor / regent / mayor and notified to the SAA no later than 7 (seven) working days after the loss of the area is known.

3. Immediately after the loss of a known area, to the treasurer, a civil servant who is not a treasurer, or other official who is in violation of the law, a statement of commitment and / or acknowledgment that the loss is the responsibility and is willing to compensate the area concerned

4. If the certificate of absolute responsibility is impossible to obtain or cannot guarantee the return of regional loss, then the governor / regent / mayor concerned immediately issues a decree assigning temporary compensation to the concerned person.

5. The imposition of regional compensation on the treasurer is determined by the SAA. If in examining the loss of the area criminal elements are found, the SAA follows up in accordance with the applicable laws and regulations.

6. The imposition of state / regional compensation on civil servants, not treasurers, or other officials is determined by the minister / leader of the institution / governor / regent / mayor. Procedures for claiming state / regional compensation are governed by government regulations.

7. Treasurers, civil servants, not treasurers, or other officials who have been determined to compensate the state / region may be subject to administrative sanctions and / or criminal sanctions.

8. Criminal decisions do not exempt from compensation claims.

\section{CONCLUSION}

The subjects of management of regional assets are the Financial Management Work Unit, RPRC, regional head / deputy regional head and regional work unit, Regional General Treasurer, Budget User, MRWU Financial Administration Officer, Activity Technical Acting Officer, Receiving Treasurer, Expenditure Treasurer. Regarding the functions of regional financial institutions in managing the regional assets of monitoring activities and the results of SAA's audits, according to Article 10 paragraph (4), it must be notified in writing to the DPR, DPD and RPRC by their authority. The position of the Financial and Development Supervisory Agency (FDSA) of the Financial and Development Supervisory Agency (FDSA) is a non-departmental government agency that is under and directly responsible for carrying out the main tasks referred to above. Recommendations that the authors suggest are related to the strategy of managing regional assets by empowering the functions of regional financial institutions, that the history of the formation of the law on state financial management and regional finance cannot be separated from the paradigm of the country as a unitary state that focuses on decentralization and regional autonomy aimed at developing capabilities and regional capacity to accelerate the realization of community welfare so that the whole process of establishing state finance law and regional financial law is directed towards the welfare of the people as embodied in the opening of the 1945 Constitution of the Republic of Indonesia. 
protection of human rights in the economy, social and culture. This has consequential implications for the management of state / regional finances, which are placed not only as legal rights but more than that state I regional financial management constitutes constitutional rights. With the reform or renewal in the regional financial accountability system, the old system that has been used by the Regional Government both provincial and district / city governments is the Regional Financial Administration Manual which has been implemented since 1981. The old system with features, including single entry (single bookkeeping), incremental budgeting (traditional budgeting routine and development) and a dynamic balanced budget approach are no longer able to meet regional needs, so there needsto be special regulations regarding the management of regional assets and not just state financial laws.

\section{REFERENCES}

Anti Coruption Clearing House Statistics, "Corruption Rate figures for years", through www.acch.CEC.go.id, accessed Monday, April 23, 2018, at 05.08 WIB.

Arifin P. SoeriaAtmadja, Public Finance in the Perspective of the Law of Practice and Criticism (Jakarta: Board of Publisher Faculty of Law of the Indonesian University, 2005), p. 15.

Asshiddiqie, Jimly. Pengantar Ilmu Hukum Tata Negara, Jakarta: PT RajaGrafindo Persada, 2016.

CEC (Antara), "CEC statistics, number of corrupt MRWUs", via www.okezone.com, accessed
Monday, April 23, 2018, at 05.47 WIB.

Hanitijo, Ronny. Legal Research Methods and Legal Writing Results in Accreditation Magazines, Law Faculty of the University of North Sumatra, February 18 2003, p. 1

Hariadi, Pramono et al. Pengelolaan Keuangan Daerah, Jakarta: Penerbit SalembaEmpat, 2010.

Karianga, Hendra. Carut Marut Pengelolaan Keuangan Daerah di Era Otonomi Daerah Perspektif Hukum dan Politik, Depok: Kencana, 2017.

Lubis, M. Solly. Hukum Tata Negara, Bandung: Mandar Maju, 2008.

Marzuki, Peter Mahmud. Penelitian Hukum, Jakarta: Prenada Media Group, 2011.

Nasution, Mulia P. Reformasi Manajemen Keuangan Pemerintah, Jurnal Forum Inovasi, DecemberFebruary 2003.

NEWS Coil, "Number of Corruption RPRC Members in 2017", through www.kumparan.com, accessed Monday, April 23, 2018, at 05.34 WIB.

Republic of Indonesia, Presidential Decree concerning the Financial and Development Supervision Agency, Presidential Decree No.31 of 1983.

Saidi, Muhammad Djafar. Hukum Keuangan Negara, Jakarta: PT RajaGrafindo Perada, 2011.

Syaukani, HR, Otonomi Daerah demi Kesejahteraan Rakyat, Jakarta: Nuansa Madani, 2004. 